\title{
UMBILICAL ARTERY DOPPLER VERSUS NON- STRESS TEST IN HIGH RISK PREGNANCIES
}

\author{
By
Yousry Omar Salim Al-Maraghy, Sileem Ahmed Sileem and Hossam Mohamed Abd El-Aaty Abd El-Hameed

Department of Obstetrics and Gynecology, Faculty of Medicine, Al-Azhar University (Assiut) Egypt

Corresponding author: Hossam Mohamed Abd El-Aaty Abd El-Hameed, Mobile: (+20) 0114123 4600, E-mail: hosamfree938@ gmail.com

\begin{abstract}
Background: Maternal monitoring of fetal movement is a mean of screening fetal status. The rationale is based on the assumption that early recognition of decreased fetal movement (DFM) makes it possible for the clinician to intervene at a stage when the fetus is still compensated, and thus prevent progression to fetal or neonatal injury or death.
\end{abstract}

Objective: To evaluate the role of non-stress test and umbilical artery Doppler measurements as an antenatal screening test for assessment of fetal well-being in high risk pregnancies affected by decreased fetal movements.

Patients and methods: The current study enrolled 200 patients complaining of decreased fetal movements came for ante natal care in ante natal care clinic of Al Azhar Assiut University Hospital. Enrolled women were randomly allocated in two equal groups, the study continued for 1 year (from January 2019 - December 2019).

Results: This study shows that the use of umbilical artery Doppler ultrasound assessment as an antenatal screening test was associated with a reduction in the incidence of cesarean delivery for fetal distress, more successful induction of labor, less admissions to NICU and better APGAR score in high risk pregnant population complaining of decreased fetal movement compared to non-stress test.

Conclusion: Umbilical artery Doppler ultrasound assessment of the fetus in conjunction with a policy of directed intervention resulted in a decrease in the rate of cesarean delivery for fetal distress in a high-risk pregnancy, when compared with the NST.

Keywords: DFM, Umbilical Artery Doppler, Non-Stress Test, High Risk Pregnancies.

\section{INTRODUCTION}

Perception of fetal movement typically begins in the second trimester, and occurs earlier in parous women than nulliparous women the mother's first perception of fetal movement is termed "quickening." Awareness of fetal movement is a means for the mother to monitor her fetus without the need for a clinician or equipment. Maternal perception of fetal movement is reassuring to pregnant women, whereas decreased fetal movement (DFM) is a common reason for concern (Gillieson et al., 2010).

Decreased fetal movement (DFM): is defined as the qualitative maternal perception of reduction of fetal movement. Several techniques for antepartum fetal surveillance are used to 
recognize fetal well-being and compromised fetuses with different sensitivity and specificity levels, those techniques include non-stress test and umbilical artery Doppler velocimetry (Smith et al., 2010).

Heart rate reactivity is believed to be a good indicator of normal fetal autonomic function. Loss of reactivity is commonly associated with a fetal sleep cycle but may result from any cause of central nervous system depression, including fetal acidosis (Alfirevic et al., 2012).

Results of non-stress tests are classified as reactive or non-reactive. Various definitions of reactivity have been used. Most commonly, the non-stress test is considered reactive, or normal, if there are two or more fetal heart rate accelerations within a 20-minute period, with or without fetal movement percepted by the woman, according to (American College of Obstetricians and Gynecologists, 2011). The non-reactive non stress test lacks sufficient fetal heart rate accelerations over a 40-minute period. The non-stress test of the neurologically healthy preterm fetus is frequently non-reactive from 24 to 28 weeks of gestation, up to 50 percent of non-stress tests may not be reactive, and from 28 to 32 weeks of gestation, 15 percent of non-stress tests are not reactive (Grant et al., 2008).

Doppler ultrasonography is used to assess the hemodynamic components of vascular impedance. Umbilical artery Doppler flow velocimetry has been adapted as a fetal surveillance technique because it is believed that flow velocity waveforms in the umbilical artery of fetuses with normal growth differ from those of fetuses with growth restriction.
The umbilical flow velocity waveform of a normally growing fetus has highvelocity diastolic flow, while in cases of intrauterine growth restriction; the umbilical artery diastolic flow is diminished. With extreme intrauterine growth restriction, the flow may be absent or even reversed. There is a high perinatal mortality rate among such pregnancies (Gill, 2011).

The aim of this study was to evaluate the role of non-stress test and umbilical artery Doppler measurements as an antenatal screening test for assessment of fetal well-being in high risk pregnancies affected by decreased fetal movements.

\section{PATIENTS AND METHODS}

The current study enrolled 200 patients complaining of decreased fetal movements came for ante natal care in ante natal care clinic of Al Azhar Assiut University Hospital. Enrolled women were randomly allocated in two equal groups, the study continued for 1 year (from January 2019 - December 2019)

Group (I): Non-stress test group of high risk pregnant women.

Group (II): Umbilical artery Doppler group of high risk pregnant women.

\section{Ethical considerations:}

The study was approved by the Scientific Ethical Committee of Faculty of Medicine, Al-Azhar University. An informed written consent was taken from every participant in the study.

In the 1st antenatal care visit all participants were subjected to:
A. Careful history taking.
B. General examination. 


\section{UMBILICAL ARTERY DOPPLER VERSUS NON-STRESS TEST IN HIGH... 989}

C. Investigations:

Complete blood picture, blood grouping and $\mathrm{Rh}$ typing.

- Renal function tests.

- Blood glucose level.

- Liver function tests.

- Ultrasonongraphic evaluation: for assessment of viability, gestational age, gross fetal malformation, amniotic fluid for oligohydramnios or polyhydramios and placenta.

Cardiographay was used to perform non-stress test results were classified into reactive or non-reactive. According to American college of Obstetricians and Gynecologists (ACOG) the non-stress test was considered reactive, or normal, if there were two or more fetal heart rate accelerations within a 15-20-minutes period, with or without fetal movement. The non- reactive non stress test lacks sufficient fetal heart rate accelerations over a 20-minutes period and repeated for another 20 minute (American College of Obstetricians and Gynecologists, 2011).

A computed sonography system (Logic GE -Korea) range-gated pulsed wave Doppler ultrasound with real time ultrasonography (Duplex system) and color flow mapping. A curved array transducer with $3.5 \mathrm{MHz}$ frequency was used for abdominal examination. The apparatus has 128 grey levels with 2-D imaging mode, spectral Doppler mode, color Doppler imaging mode and fetal Mmode, Umbilical artery Doppler ultrasound indices (included resistant index (RI), pulsatility index (PI) and systolic/diastolic ratio(S/D ratio) were done for all participants using trans abdominal ultrasound. The patients were put in semi-recumbent position; the end of the transducer was applied to the upper abdomen slightly above umbilicus but variation may be present sometimes.

The peak systolic and end diastolic frequency shifts were recorded; systolic, diastolic ratio, resistance index and pulsatility index were calculated according to the following formulas:

- $\quad \mathrm{RI}=\mathrm{S}-\mathrm{D} / \mathrm{S}$

- $\quad \mathrm{PI}=\mathrm{S}-\mathrm{D} / \mathrm{Mean}$

- $\quad \mathrm{S} / \mathrm{D}=$ systole/diastole

Where: $\mathrm{S}=$ peak systolic velocity. $\mathrm{D}=$ End-diastolic flow.

Mean $=$ requires digitized waveform analysis for calculation.

\section{The cut-off levels were considered if:}

- $\mathrm{RI}>0.70$ was considered abnormal.

- $\quad$ PI >0.99 was considered abnormal.

- $\quad$ S/D ratio value $>4$ was considered abnormal.

\section{Follow up visits concluded:}

- Careful history for any evidence suggesting abnormal fetal wellbeing.

- Clinical examination for abnormal gain of weight, any elevation of blood pressure, pathological edema of both lower limbs, obstetric examination.

- Investigations:

- $\quad$ Routine investigations.

- $\quad$ Non stress test for Group (I).

- Umbilical artery Doppler for Group (II).

Protocol of managements: 
For non-stress test group (Group I):

- Patients with normal non-stress test were discharged and followed up every one week until the expected date of delivery.

- Patients with non-reactive non stress test the test were repeated after 3 days.

According to the results of 2nd testing the following was done:

- Patients with normal non-stress test: were discharged and followed up every one week until the expected date of delivery.

- Patients with abnormal non-stress test: induction of labor was offered after induction of lung maturity by Dexamethason.

For umbilical artery Doppler group (Group II):

- Patients with normal umbilical artery Doppler: were discharged and followed up every one week until the expected date of delivery.
- Patients with abnormal umbilical artery Doppler findings: induction of labor was offered after induction of lung maturity by Dexamethason.

All patients were followed up until delivery to determine fetal outcomes.

\section{Statistical analysis:}

The data in this study were analyzed using the statistical package for the social science (SPSS 10 for windows, version II). The analysis was performed using the following procedures. Student's test (ttest): was used to check the significance between continuous data (quantitative items between two different groups). Chisquare test (X2): Was used to check the significance between categorical data (qualitative items between two different groups). The probability of significance ( $\mathrm{P}$ value): The probability $(\mathrm{P}$ value $<0.05)$ was taken as the limit of statistical significance.

\section{RESULTS}

Mean age of NST group was $29.15 \pm$ 2.22 years with range between 25 and 34 years while mean age Doppler group was $28.99 \pm 3.98$ years with range between 24 and 35. It was noticed that there were insignificant differences between both groups as regarding baseline sociodemographic data (Table 1). 


\section{UMBILICAL ARTERY DOPPLER VERSUS NON-STRESS TEST IN HIGH...91}

Table (1): Sociodemographic characteristics of the studied groups

\begin{tabular}{|c|c|c|c|c|c|}
\hline \multirow{3}{*}{ Characteristics } & \multirow{2}{*}{\multicolumn{2}{|c|}{$\begin{array}{l}\text { NST Group } \\
(\mathrm{n}=100)\end{array}$}} & & & \multirow{3}{*}{ P-value } \\
\hline & & & & roup & \\
\hline & No. & $\%$ & No. & $\%$ & \\
\hline \multicolumn{5}{|l|}{ Age (years) } & \multirow{3}{*}{$>0.05$} \\
\hline$<30$ years & 60 & $60 \%$ & 62 & $62 \%$ & \\
\hline$\geq 30$ years & 40 & $30 \%$ & 38 & $38 \%$ & \\
\hline Mean \pm SD & \multicolumn{2}{|c|}{$29.15 \pm 2.22$} & \multicolumn{2}{|c|}{$28.99 \pm 3.98$} & \multirow{2}{*}{$>0.05$} \\
\hline Range & \multicolumn{2}{|c|}{$(25-34)$} & \multicolumn{2}{|c|}{$(24-35)$} & \\
\hline \multicolumn{5}{|l|}{ Social class } & \multirow{4}{*}{0.05} \\
\hline Low & 19 & $19 \%$ & 14 & $14 \%$ & \\
\hline Middle & 49 & $49 \%$ & 51 & $51 \%$ & \\
\hline High & 32 & $32 \%$ & 35 & $52 \%$ & \\
\hline \multicolumn{5}{|l|}{ Residence } & \multirow{3}{*}{0.05} \\
\hline Rural & 56 & $56 \%$ & 60 & $60 \%$ & \\
\hline Urban & 44 & $44 \%$ & 40 & $40 \%$ & \\
\hline \multicolumn{5}{|l|}{ Educational level } & \multirow{5}{*}{$>0.05$} \\
\hline Illiterate & 30 & $30 \%$ & 28 & $28 \%$ & \\
\hline Basic education & 15 & $15 \%$ & 22 & $22 \%$ & \\
\hline Secondary & 25 & $25 \%$ & 22 & $22 \%$ & \\
\hline High education & 30 & $30 \%$ & 28 & $28 \%$ & \\
\hline \multicolumn{5}{|c|}{ Gestational age at recruitment (weeks) } & \multirow{3}{*}{$>0.05$} \\
\hline$<38$ weeks & 53 & $53 \%$ & 50 & $50 \%$ & \\
\hline$\geq 38$ weeks & 47 & $47 \%$ & 50 & $50 \%$ & \\
\hline Mean \pm SD & \multicolumn{2}{|c|}{$36.56 \pm 0.97$} & \multicolumn{2}{|c|}{$36.10 \pm 1.1$} & \multirow{2}{*}{$>0.05$} \\
\hline Range & \multicolumn{2}{|c|}{$(33-40)$} & \multicolumn{2}{|c|}{$(33-40)$} & \\
\hline \multicolumn{5}{|l|}{ Fetal sex } & \multirow{3}{*}{$>0.05$} \\
\hline Male & 60 & $60 \%$ & 56 & $56 \%$ & \\
\hline Female & 40 & $40 \%$ & 44 & $44 \%$ & \\
\hline \multicolumn{5}{|c|}{ Number of antenatal care visits } & \multirow{4}{*}{$>0.05$} \\
\hline One & 10 & $10 \%$ & 13 & $13 \%$ & \\
\hline Two & 25 & $25 \%$ & 22 & $22 \%$ & \\
\hline More than two & 65 & $65 \%$ & 65 & $65 \%$ & \\
\hline
\end{tabular}

NST: non-stress test

The most frequent risk factors in NST group were diabetes mellitus (DM) (22\%), preterm labor (PTL) (18\%) and premature rupture of membrane (PROM) (14\%) while the most frequent risk factors in Doppler group were DM (23\%), preeclampsia (14\%) and previous intrauterine growth restriction (IUGR) $(14 \%)$. It was noticed that both groups had insignificant differences as regarding risk factors (Table 2). 
Table (2): Classification of participants of both groups according to the risk factors

\begin{tabular}{|c|c|c|c|c|c|}
\hline \multirow{2}{*}{ Risk factor } & \multicolumn{2}{|c|}{$\begin{array}{l}\text { NST Group } \\
(\mathbf{n}=\mathbf{1 0 0 )}\end{array}$} & \multicolumn{2}{|c|}{$\begin{array}{c}\text { Doppler Group } \\
(\mathrm{n}=100)\end{array}$} & \multirow[t]{2}{*}{ P-value } \\
\hline & No. & $\%$ & No. & $\%$ & \\
\hline Diabetes mellitus & 22 & $22 \%$ & 23 & $23 \%$ & $>0.05$ \\
\hline Gestational hypertension & 11 & $11 \%$ & 12 & $12 \%$ & $>0.05$ \\
\hline Placenta previa & 5 & $5 \%$ & 6 & $6 \%$ & $>0.05$ \\
\hline Polyhydramnios & 4 & $4 \%$ & 6 & $6 \%$ & $>0.05$ \\
\hline Preeclampsia & 13 & $13 \%$ & 14 & $14 \%$ & $>0.05$ \\
\hline Previous IUGR & 12 & $12 \%$ & 14 & $14 \%$ & $>0.05$ \\
\hline PROM & 14 & $14 \%$ & 12 & $12 \%$ & $>0.05$ \\
\hline PTL & 18 & $18 \%$ & 11 & $11 \%$ & $>0.05$ \\
\hline Anemia & 7 & $7 \%$ & 5 & $5 \%$ & $>0.05$ \\
\hline History of CFMF & 4 & $4 \%$ & 5 & $5 \%$ & $>0.05$ \\
\hline
\end{tabular}

Data expressed as frequency (percentage). IUGR: intrauterine growth restriction; PROM: premature rupture of membrane; PTL: preterm labor; CFMF: congenital fetal malformations; NST: nonstress test.

Table (3): Results of NST in the 1st and 2nd antenatal care visits in group I

\begin{tabular}{|l|c|c|c|}
\hline Visits & $\begin{array}{c}\mathbf{1}^{\text {st }} \mathbf{A N C} \text { visit } \\
(\mathbf{n = 1 0 0})\end{array}$ & $\begin{array}{c}\mathbf{2}^{\text {nd }} \mathbf{A N C} \text { visit } \\
(\mathbf{n}=\mathbf{6 0})\end{array}$ & P1. Value \\
\hline Reactive & $40(40 \%)$ & $40(66.7 \%)$ & $<0.001$ \\
\hline Non-reactive & $60(60 \%)$ & $20(33.3 \%)$ & \\
\hline P2. Value & $<0.005$ & $<0.001$ & \\
\hline UAD & $\begin{array}{c}1^{\text {st }} \text { antenatal care } \\
\text { visits }(\mathrm{n}=100)\end{array}$ & $\begin{array}{c}2^{\text {nd }} \text { antenatal care } \\
\text { visits }(\mathrm{n}=30)\end{array}$ & P1. value \\
\hline Normal & $70(70 \%)$ & $10(33.3 \%)$ & $<\mathbf{0 . 0 0 1}$ \\
\hline Abnormal & $30(30 \%)$ & $20(66.7 \%)$ & \\
\hline P2. Value & $<0.01$ & $<0.001$ & \\
\hline
\end{tabular}

There was a statistically significant difference between both tests as regard to abnormal results; the abnormal test results
There were statistically significant difference between $1^{\text {st }}$ visit and $2^{\text {nd }}$ visit as regarding result of NST \& UAD (Table 3). were significantly higher in NST group in $1^{\text {st }}$ visit and higher in UAD group in $2^{\text {nd }}$ visit (Table 4).

Table (4): Abnormal results of both groups in the 1st and 2nd antenatal visits

\begin{tabular}{|c|c|c|c|}
\hline Visit & $\begin{array}{c}\text { NST group } \\
(\mathbf{n}=100)\end{array}$ & $\begin{array}{c}\text { UAD group } \\
(\mathbf{n}=\mathbf{1 0 0})\end{array}$ & P value \\
\hline $\mathbf{1}^{\text {st }}$ visit & $60 / 100(60 \%)$ & $30 / 100(30 \%)$ & $<\mathbf{0 . 0 0 1}$ \\
\hline $\mathbf{2}^{\text {nd }}$ visit & $20 / 60(33.3 \%)$ & $20 / 30(66.7 \%)$ & $<\mathbf{0 . 0 0 1}$ \\
\hline
\end{tabular}

UAD: umbilical artery Doppler; NST: non stress test

There were statistically significance between NST and UAD where successful induction was higher in UAD group (65 vs. 25\%; p. value < 0.001) (Table 5). 


\section{UMBILICAL ARTERY DOPPLER VERSUS NON-STRESS TEST IN HIGH...93}

Table (5): Induction of labor for abnormal test results for both groups

NST: non-stress test

\begin{tabular}{|c|c|c|c|c|c|}
\hline \multirow{2}{*}{$\begin{array}{c}\text { Groups } \\
\begin{array}{c}\text { Results of } \\
\text { induction }\end{array}\end{array}$} & \multicolumn{2}{|c|}{$\begin{array}{c}\text { NST Group } \\
(\mathbf{n = 2 0})\end{array}$} & \multicolumn{2}{c|}{$\begin{array}{c}\text { Doppler Group } \\
(\mathbf{n = 2 0})\end{array}$} & \multirow{2}{*}{ P-value } \\
\cline { 2 - 5 } & No. & $\%$ & No. & $\%$ & \\
\hline Succeed & 5 & 25 & 13 & 65 & $<0.001$ \\
\hline Failed & 15 & 75 & 7 & 35 & \\
\hline
\end{tabular}

It was found that the rate of vaginal delivery was statistically higher in UAD group $(70 \%$ vs. $60 \% \mathrm{p}<0.05)$, while CS rate was statistically higher in NST group (40\% vs. 30\%) (Fig. 1).

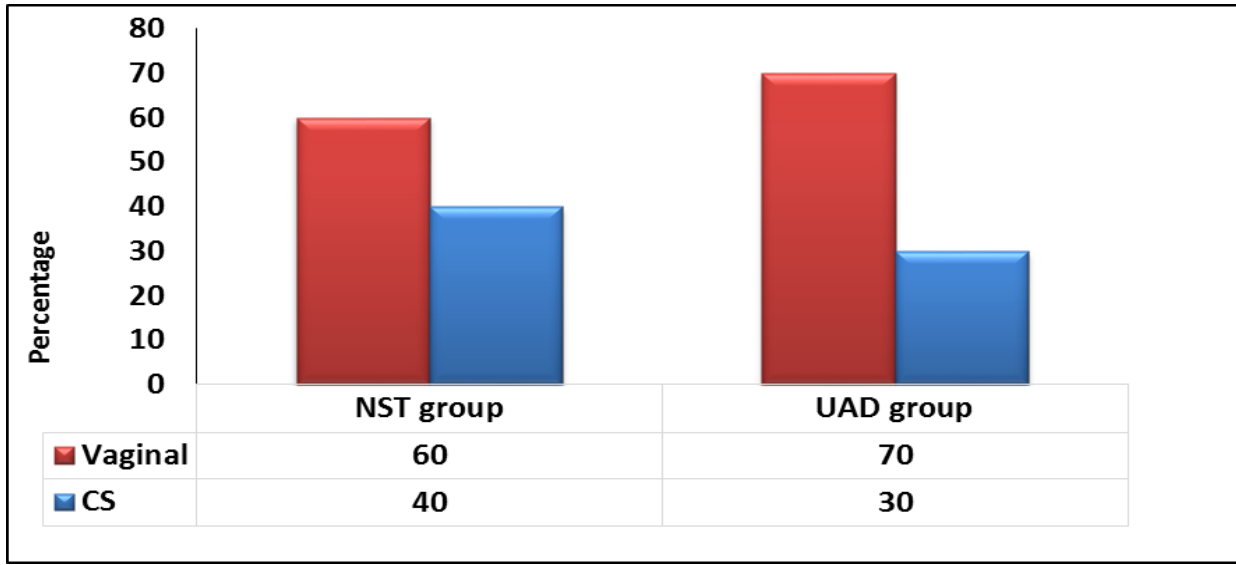

Figure (1): Mode of delivery and fetal outcomes in NST group and UAD groups

There was a significant difference in APGAR scores $<4$ at 1 minute $(20 \%$ vs.4\%) and APGAR score 5 minutes $>7$ (80\% vs. $96 \%$ ) between NST and UAD groups respectively $(\mathrm{p}<0.001)$. Also, the admission to neonatal intensive care unit (NICU) was higher for neonates (Table 6).

Table (6): Fetal outcomes of the studied groups

\begin{tabular}{|c|c|c|c|c|c|}
\hline & \multicolumn{2}{|c|}{$\begin{array}{l}\text { NST group } \\
(\mathbf{n}=100)\end{array}$} & \multicolumn{2}{|c|}{$\begin{array}{l}\text { UAD group } \\
(\mathbf{n}=\mathbf{1 0 0})\end{array}$} & P-value \\
\hline \multicolumn{6}{|l|}{ APGAR score } \\
\hline 1-min APGAR score $<4$ & 20 & 20 & 4 & 4 & \multirow{2}{*}{$<0.001$} \\
\hline 5-min APGAR score >7 & 80 & 80 & 96 & 96 & \\
\hline \multicolumn{6}{|c|}{ State of admission to NICU } \\
\hline NO & 87 & 87 & 97 & 97 & \multirow{2}{*}{$<0.001$} \\
\hline YES & 13 & 13 & 3 & 3 & \\
\hline \multicolumn{6}{|c|}{ Cause of admission to NICU } \\
\hline Diabetes mellitus & 5 & 5 & 1 & 1 & \multirow{4}{*}{0.789} \\
\hline Hypertension & 3 & 3 & 1 & 1 & \\
\hline Preeclampsia & 4 & 4 & 1 & 1 & \\
\hline Previous IUGR & 1 & 1 & -- & -- & \\
\hline \multicolumn{6}{|c|}{ Gestational age at time of admission to NICU } \\
\hline$<37$ weeks & 5 & 5 & 1 & 1 & \multirow{2}{*}{0.379} \\
\hline$\geq 37$ weeks & 8 & 8 & 2 & 2 & \\
\hline
\end{tabular}


Data expressed as frequency (percentage). NST: non-stress test; UAD: umbilical artery Doppler; NICU: neonatal

\section{DISCUSSION}

In the present study there were no statistically significant differences between both groups as regards to other sociodemograhic characteristics.

It was found that the percentage of non-reactive NST in the $1^{\text {st }}$ ANC visit was $60 \%$. When NST was repeated after one weak 40 out of the 60 patients with nonreactive test became reactive while only 20 patients remained non-reactive so the percentage of non-reactive NST among high risk patients with decreased fetal movements had dropped from $60 \%$ in the $1^{\text {st }}$ ANC visit to $20 \%$ in the $2^{\text {nd }}$ ANC visit and the difference was statistically very highly significant.

The difference in results between the two consecutive test results could be attributed to the presence of false positive results for NST. This finding is in agreements with (Neilson, 2010) who estimated false positive results of NST in different risk factors to vary from $35-65 \%$ and they concluded that NST should be performed at least twice to decrease this false positive result.

It was found that the percentage of abnormal UAD in the $1^{\text {st }}$ ANC visit was $30 \%$. When the test was repeated after one weak 10 out of the 30 patients with abnormal test became normal while only 20 patients remained abnormal so the percentage of abnormal test among high risk patients with decreased fetal movements had dropped from $30 \%$ in the $1^{\text {st }}$ ANC visit to $20 \%$ in the $2^{\text {nd }}$ ANC visit and the difference was statistically highly intensive care unit; IUGR: intrauterine growth restriction

significant. The difference in results between the two consecutive test results could be also attributed to the presence of false positive results for UAD.

In the $1^{\text {st }}$ ANC visit: The incidence of abnormal test results was $(60 \%$ vs. $30 \%)$ for NST and UAD groups respectively and the difference was statistically significant.

In the $2^{\text {nd }}$ ANC visit: The incidence of abnormal test results was $20 \%$ vs. $20 \%$ for NST and UAD groups respectively and the difference was statistically significant $(\mathrm{p}<0.05)$.

These differences between abnormal test results in NST and UAD groups in both $1^{\text {st }}$ and $2^{\text {nd }}$ antenatal care visits could be attributed to higher false positive results of NST compared to UAD.

The results of our study was found to be similar to (Morrissette et al., 2012) who reported in their study a higher falsepositive rate for non-stress test than umbilical artery Doppler (39\% vs. 22\%), they concluded that repetition of nonstress test is recommended to decrease the higher false positive results. Also, Morris et al. (2011) stated that in high-risk populations, fetal umbilical artery Doppler is a moderately useful test to predict mortality and risk of fetal compromise.

As a result of the presence of false positive results for the antenatal screening tests for fetal wellbeing, investigators recommend either repetition of NST (Morrissette et al., 2012) or the test is to be applied to multiple fetal vessels in case 


\section{UMBILICAL ARTERY DOPPLER VERSUS NON-STRESS TEST IN HIGH...95}

of Doppler studies (Khanduri et al., 2017) to increase the sensitivity of these tests.

In the current study the rate of successful induction of labor was significantly higher in UAD group $(65 \%$ vs.25\% for UAD and NST groups respectively). This result is in accordance with (Roger et al., 2017) who found that more patients in the Doppler group required an induction of labor than in NST group.

Finding of the current study could be attributed to the fact that Doppler assessment identified a higher proportion of patients with early placental compromise than the NST assessment that allows successful induction of labor before the occurrence of placental decompensating. Concomitantly this increased rate of induction did not result in an increase in the overall rate of cesarean delivery. In addition, there was no increase in the rate of cesarean delivery for failure to progress in the Doppler group.

In the present study there were a significant difference in APGAR scores < 4 at 1 minute (20\% vs.4\%) and APGAR score 5 minutes $>7 \quad(80 \%$ vs. $96 \%)$ between NST and UAD groups respectively. also the admission to neonatal intensive care unit (NICU) was higher for neonates of NST group than UAD group (13\% vs. 3\% respectively $\mathrm{p}<0.001)$. these results was found to be similar to (Morris et al , 2014), (Roger et al.,2017) and (Morrissette et al.,2012).

The use of non-stress test for antenatal testing in several large studies show no improvement in perinatal outcome, with a sensitivity to predict perinatal morbidity of $60 \%$ and a specificity of $<50 \%$.In the
Cochrane meta-analysis of four trials in which electronic fetal monitoring was the primary means of surveillance, there was no significant improvement in the rate of admissions to the neonatal intensive care unit, cesarean delivery rates, the incidence of low APGAR scores at birth, or abnormal neonatal neurologic signs. Doppler ultrasound scanning was introduced to investigate the umbilical artery blood flow pattern in high-risk pregnancies that were at risk for fetal compromise (Michael et al., 2010).

This study showed that the use of umbilical artery Doppler ultrasound assessment as an antenatal screening test is associated with a reduction in the incidence of cesarean delivery for fetal distress, more successful induction of labor, less admissions to NICU and better APGAR score in high risk pregnant population complaining of decreased fetal movement compared to non-stress test.

\section{CONCLUSION}

1. Umbilical artery Doppler ultrasound assessment of the fetus in conjunction with a policy of directed intervention results in a decrease in the rate of cesarean delivery for fetal distress in a high-risk pregnancy, when compared with the NST.

2. The introduction Doppler ultrasound assessment as a primary screening test must be balanced against a higher rate of secondary testing by amniotic fluid index, training of personnel to perform these tests.

3. umbilical artery Doppler velocimetry has more significant than non-stress test due to it is reduce incidence of cesarean section in case of non-reactive 
non stress test without increase in perinatal morbidity and mortality rate.

\section{RECOMMENDATIONS}

1. Use of umbilical artery Doppler velocimetry as screening tools in high risk pregnancy is very important to decreased perinatal morbidity and mortality rate.

2. Larger prospective randomized, controlled trials are necessary to determine the significance of these tests in specific subgroups for the reduction in other aspects of perinatal morbidity and death.

\section{REFERENCES}

1. Alfirevic Z, Devane $D$ and Gyte GM. (2012): Continuous cardiotocography (CTG) as a form of electronic fetal monitoring (EFM) for fetal assessment during labour. Cochrane Database Syst. Rev; 3:CD006066.

2. American College of Obstetricians and Gynecologists (2011): ACOG Practice Bulletin. Clinical Management Guidelines for Obstetrician-Gynecologists, Number 70, December 2011. (Replaces Practice Bulletin Number 62, May 2011). Intrapartum fetal heart rate monitoring. Obstetrics and Gynecology, 106 (6): 1453-60.

3. Cibils LA, Ylsma-Howell M, Shamsi S, Towel ME (2017): A scoring system for nonstressed antepartum fetal heart rate monitoring Am J Obstet Gynecol., 133:2426.

4. Gill RW. (2011): Pulsed Doppler with Bmode imaging for quantitative blood flow measurement. Ultrasound Med Biol., Ultrasound Med Biol., 5(3):223-35.

5. Gillieson M, Dunlap H, Nair R and Pilon M. (2010): Placental site, parity, and date of quickening. Obstet Gynecol. 2- 64:44.

6. Fretts RC, Elbourne D, Valentin L and Alexander S (2019): Routine formal fetal movement counting and risk of antepartum late death in normally formed singletons. Lancet, 2(8659):345-349.

7. Khanduri S, Rajagopal KV, Gourisankar PT (2017): Doppler prediction of adverse perinatal outcome in PIH and IUGR, Ind J Radiol Immage, 16: 109-116.

8. Michael G, Micki L, Kellner L, Plancher S, Maulik D. (2010): Computerized analysis of fetal heart rate variation inpost term pregnancy: prediction of intrapartum fetal distressand fetal acidosis. Am J Obstet Gynecol., 171:1132-8.

9. Morris RK (2014): Assessment of amniotic fluid volume in at-risk pregnancies. Clin Obstet Gynecol., 38:78-90.

10. Morris RK, Malin G, Robson SC, Kleijnen J, ZAMORA J, Khan KS (2011): Fetal umbilical artery Doppler to predict compromise of fetal/neonatal wellbeing in a high-risk population: systematic review and bivariate meta-analysis Ultrasound Obstet Gynecol., 37: 135-142.

11. Morrissette, Griz BA, Lieeblich R, Langer $O$ (2012): Clinical management of the fetus with markedly diminished umbilical artery end-diastolic flow. Am J Obstet Gynecol., 161:1523-7.

12. Neilson JP \& Alfirevic Z. (2010): Doppler ultrasound for fetal assessment in high risk Pregnancies. Cochrane Database Syst Rev. CD000073.

13. Roger PS, Duncan FF, Michael B, Jerome D, France G, Wilson RD, Dorothy S, Nancy K (2017): Screening for fetal wellbeing in a high-risk pregnant populationcomparing the nonstress test with umbilical artery Dopplervelocimetry: A randomized controlled clinical trial. Am J Obstet Gynecol., 188: 1366-1371.

14. Smith CV, Davis SA and Rayburn WF. (2010): Patients' acceptance of monitoring fetal movement. A randomized comparison of charting techniques. J Reprod Med., 14: $37: 144$. 
UMBILICAL ARTERY DOPPLER VERSUS NON-STRESS TEST IN HIGH...97

\section{دوبلر الشريان السري مقابل اختبار عدم الإجهاد فى حالات الحمبل

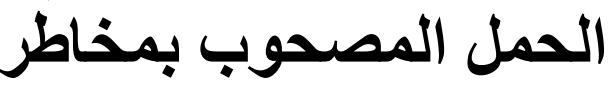

يسرى عمر سليم المراغى، سليم أحمد سليم، حسام محمد عبد العاطى عبد الحميد قسم التوليد وأمراض النساء، كلية الطب، جامعة الأزهر(أسيوط)، مصر

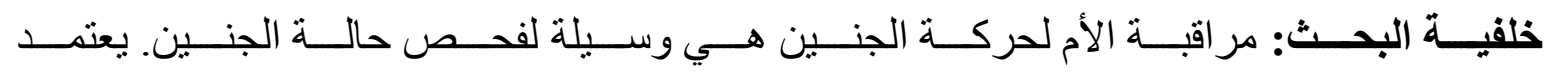

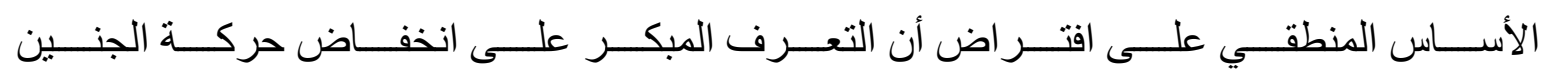

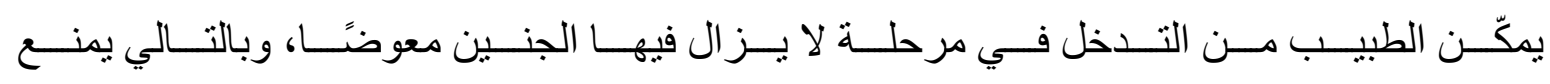
تطور إصابة الجنين أو حديثي الولادة أو الوفاة.

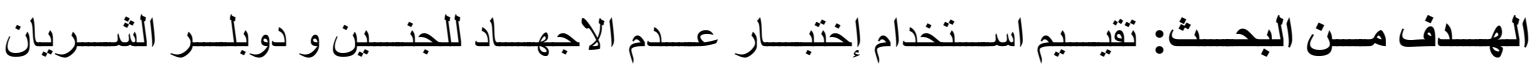
السري في حالات الحمل الخطر المصاحب بنقص حركة الجنين.

المريضــات وطــرق البحــث: تــم إجـر اء هــذه الدر اســة علــى مــائتين مــن الســبدات اللاتــي

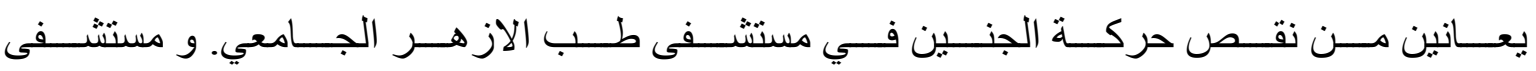

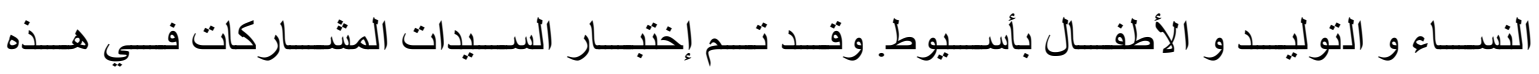

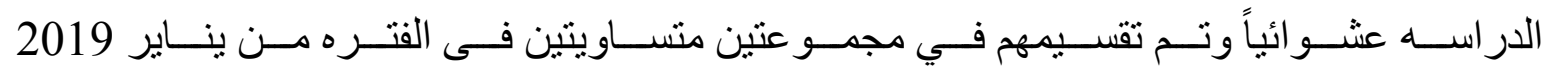
الى ديسمبر 2019.

نتــائج البحــث: تبــين هــذه الدر اســـة أن اختبــار دوبلــر الثــريان الســرى للجنـين بــالتز امن

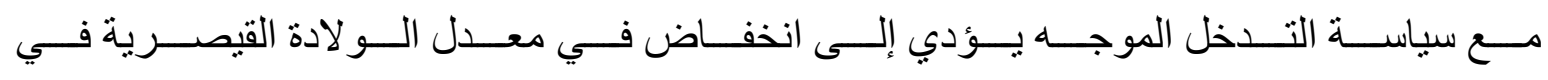
الحمل الخطر المصحوب باعياء الجنين مقارنه باختبار عدم الاجهاد.

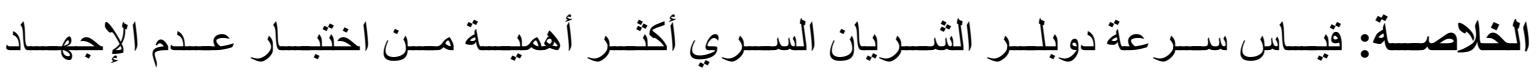

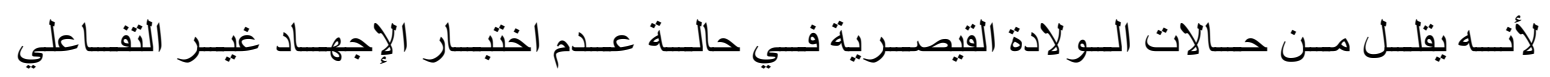
دون زيادة في معدل المرض و الوفيات في الفترة المحيطة بالو لادة. 